\title{
Factors That Have the Potential to Cause of Street Child Violence at Ambengan Surabaya
}

\author{
Naili Sa'ida ${ }^{1}$, Anisa Yunitasari ${ }^{2}$ \\ \{nailisaida@fkip.um-surabaya.ac.id ${ }^{1}$, anisa.yunita@narotama.ac.id ${ }^{2}$ \} \\ Muhammadiyah University of Surabaya ${ }^{1}$, Narotama University ${ }^{2}$
}

\begin{abstract}
This study was aimed at describing the presence of child abuse in the family and the causes of the violence. The study was conducted to street children at Ambengan, Surabaya, Indonesia. A qualitative method was administrated using the data collection techniques of observation, interview, and documentation. Besides, the data analysis technique was based upon the technique of data analysis interactive model of Miles and Huberman, which included data collection, data reduction, data display, and verification. Besides, triangulation techniques were used to test the validity of the data. The results revealed that violence against children happened due to several factors as follows:1) family factor that included broken home, family psychologically immature, and the education level of parents. 2) environmental social / community factor, the family financial matters, and 3) the internal factors of the child. Furthermore, this study exhibited focal point that the impacts of violence on children led to the worse of child's psychological growth and character. In other word, children who were exposed to violence were likely to be rebels, dropouts, temperamental, and indifferent to the environments, particularly families. In addition, this study found that parents' parenting activity could affect children's emotions.
\end{abstract}

Keywords: Children, Violence, Family

\section{Introduction}

Children are the shoots, the potential, and the future generation which have a pivotal role in the future furtherment of a nation. Hence, children need to get their rights to grow and develop optimally. The rights include the right to life, growing rights, the right to protection, and the right to participate.

In fact, the condition of children in Indonesia is getting to deteriorate. The days of children who should be colored with activities to play, learn, and develop an interest and talent for future supplies, unfortunately, is colored with dark and depressing data. Considerable Indonesian children are still subjected to violence, whether physical, verbal, psychological, or sexual.

According to Sindonews.com on March 19, 2018, it is reported that child abuse increased in 2018, there were 1980 reports of child abuse throughout Indonesia. Meanwhile, according to Tirto.id in November 2017, it is mentioned that 73.7 percent of Indonesian children abused at home. These data indicate that families who suppose to be able to be protective of children, unfortunately, do a lot of violence to children. Undoubtedly, considerable news today is related to persecution, rape and even murder committed by his own relatives, even biological parents. 
Survey of violence from Tirto.id also showed that 41.1 percent of boys getting physical violence from father and 35.6 percent of them getting emotional abuse from his father. Girls tend to get physical and emotional abuse from the mother[1]. This is confirmed by the data as much as 66.34 percent of girls getting physical violence and 49.81 percent of the capital gain from the mother's emotional abuse. Undoubtedly, These needs to get attention. The parents' behavior has a significant influence on the development of children with the same sexed[1]. This means that problematic daughter behaviors associated with violence by mothers than fathers. Likewise, boys closely related to their experience with their father.

According to Law No. 23 of 2002 on the protection of rights of children, children get the right protection to make a living, body, develops, and perpartisipasi optimally with human dignity, and protection from violence and discrimination[2]. This shows the child the right to protection from violence and discrimination, either from family, society, and the environment.

\subsection{Violence on Children}

Abuse as improper behavior intended to cause physical, psychological, or financial harm to an individual or group[3]. Violence is inappropriate behavior that resulted in harm or danger physically, psychologically, or financially, whether experienced by individuals and groups. Violence against children is a deliberate act that causes harm or danger to the children physically and emotionally. Furthermore, Barker) also posits that violence against children is repeated acts of physical and emotional abuse of child dependency, via urges, corporal punishment is uncontrollable, degradation and insults permanent or sexual violence, usually done by the parents or other parties who should care for the child[5].

The Nativism pioneered by Rousseou argues that all children born innately good, and good disposition affected child will become worn from the environment[6]. This elaboration indicates that by nature, every human being instinctively has good dispositions, often called the conscience, but these good traits to become insensitive if the state of the social environment does not support. If children are accustomed to exposure to violence, then conscience is not sensitive and does not even work anymore so rationally it will be infused in the mind of the child that violence is a common thing to do. When the child grows up, he will grow into an unscrupulous, if he/she becomes a parent he/she will also do violence in the family, this chain will continue from generation to generation. The explanation is in accordance with the opinion of another researcher which states that human beings are creatures of monodualism, individuals at once a social being.

Tabula rasa theory propounded by John Locke said that the human condition at birth is likened to a tabula rasa. Graffiti or the existing color on the paper is determined by the parents and the surrounding environment. John Locke opinion is also aligned with the social learning theory proposed by Albert Bandura which states that human behavior can be predicted, modified through learning principles with the capability of thinking and their social interactions[7]. This shows the importance of how to educate and raise children, but it is often found that verbal and physical abuses frequently come from parents or the surrounding environment. One of the things that triggered child abuse is that parents do not have a good understanding of the child's psychological development phase, especially when children are in a difficult phase so that the child is labeled as naughty children, while it is normal in all children. Child difficult phase, in the psychological world, is more often called a temper tantrum. Shelov in the book "Caring For Your Baby And Your Child" suggests that temper tantrums are an expression of frustration child[8]. According to Vasta, temper tantrums are an expression of emotion and stimulus response to an internal or external individuals [9]. 
In this difficult phase, children should get proper treatment because unconsciously they are building an understanding to recognize and process their emotions, of which it is the foundation for character formation in children. At this time, there comes a process of formation of the brain and behavior. This period is also considered a critical period for emotional and psychological development. Superego development began to occur, and consciousness began to emerge. Delinquency in this period is a natural thing because in this way, the child to explore the world around them. However, considerable parents assume that the boy had done something unusual and disturbing, so parents tend to verbal abuse and even physical violence like yell, hit, or pinch.

\subsection{Types of violence against children}

There are several types of violence against children, as follows:

1. Physical abuse

Physical violence is a form of violence that is given physically, such as hitting, kicking, pinching, all forms of persecution that cause physical injury or death to the child. Physical abuse in children generally occurs because the behavior of children who do not like old people like fussing, crying, asking for something, defecation, tantrums, and so on.

2. Verbal violence

Verbal abuse likes yelling and bullying. Verbal abuse has a significant effect on children's psychology. Children who are too often get verbal violence to tend to be rebellious child, daring with adults, love to say loud and temperamental.

3. Sexual violence

Child sexual violence can be either pre-treatment sexual contact between children and the greater good through words, touch, visual images, or direct treatment of sexual contacts such as incest, rape, or sexual exploitation. Sexual harassment is prone to occur in children with the lower family economy (poor) and street children[10]. People of low economic majority justifies any means to make ends meet.

4. Social violence

Social violence in children includes neglect and exploitation of children. Neglect of children is the attitude and treatment of parents who do not give proper attention to children. Furthermore, the exploitation of children constitutes discrimination or abuse against children carried the family or community. Example: forcing children to beg, forcing the child to force the child to do chores that exceed the limit of their ability.

\subsection{Determinant Factors of Children Violence}

The factors that cause violence in children include family factors/parents, environmental factors, and social / community, and child factors alone[11].

1. Parents / family factor

Family factor plays an important role to induce child abuse and negligence. The family factor that causes violence in children include: a) cultural practices that harm children: Child obedience to parents, an asymmetrical relationship. b) children are raised by persecution. c) mental disorders. d) has not reached physical maturity, emotional and social, especially those who have children before the age of 20 years. e) alcoholics and drugs. 
2. Social / Community Environment Factor

The social environment can also trigger the occurrence of child abuse. Social environmental factors that can lead to abuse and neglect in children include: poverty in the community and pressure materialistic values; socio-economic conditions were low, their values in society that the child is the parent's own, the status of women despised, system patriarchal family, and value low individualistic society.

3. The Children Per Se Factor

Children factor include child developmental disorders having a chronic disease caused by the dependence of children to their environment, and deviant behavior in children.

Gelles explains that the consequences of child abuse and negligence can cause extensive damage and effects, such as physical injuries: bruises, scratches, and burns to brain damage, permanent disability, and death[12]. The psychological effects on children victims of violence can be carried for life, such as: a sense of low self-esteem, the inability to relate with peers, reduced attention span, and learning disorders. In some cases of violence could also result in psychiatric disorders, such as depression, excessive anxiety, dissociative identity disorder, and increased risk of suicide. From this opinion, the visible impact of violence against children is so alarming. Considerable people are not aware that the beating of a physical nature can cause emotional damage to the child.

\section{Research Methods}

The samples were 3 street children who had experienced violence Ambengan Surabaya from his family. The data collection techniques used were observation, interviews, and documentation. This study used data analysis techniques proposed by Miles and Huberman, which included data collection, data reduction, data presentation, and final conclusion. The validity of data was tested by using a member check.

\section{Results and Discussion}

Table 1. Data of Research Subject

\begin{tabular}{ccccccc}
\hline No. & $\begin{array}{c}\text { Research } \\
\text { subjects }\end{array}$ & Gender & Age & $\begin{array}{c}\text { Level of } \\
\text { education }\end{array}$ & Job & Marital status \\
\hline 1. & R1 & Female & 25 & Elementary & labor & Divorce \\
2. & R2 & Male & 53 & $\begin{array}{c}\text { Elementary } \\
\text { Junior } \\
\text { cycle rickshaw }\end{array}$ & Intact \\
3. & R3 & Female & 28 & Clerk & Intact \\
\hline
\end{tabular}

Table 1 showed that Respondent 1 or R1 was female and 25 years old. R1 had a primary school education background, and she worked as a laborer. She was a single parent of two children, five year old girl called CT and 8-year old son called AR. Both children did not go to school because R1 did not have fees to send their children. AR worked as a newspaper seller at the intersection Ambengan region. On Friday night, AR participated in a non-formal voluntary school conducted by SSCS. R1 often scolded AR when the AR did not want to take 
care of his sister at the time of R1 work. Not only scolded AR and CT also often get a blow in the form of physical violence. CT often got pinch by R1 when she was fussy. Being asked the cause, R1 abusive to their children was due to discipline her child. R1 think otherwise with his violence will not be obeyed. R1 did violence to educate children. She did not think about the implications for the child. AR into a child who has a rough and rebellious attitude. AR always against what his parents said. Although he wanted to sell, it tends indifferent to his sister. He preferred to be on the streets than return home. He sold newspapers until late at night.

Respondents 2 or R2 was a 26 year male. The educational background of R2 was the only primary. He worked as a rickshaw in front of the station Gubeng. He had two children. LP was his first child who was 13 years old girl. IN was his second child who was a 10-year-old girl. R2 wife worked as a seller of coffee. Both children of R2, after school, help their parents to sell coffee and sell magazines at the crossroad. At the time the researchers observed several times, the researchers saw that the LP was still selling the coffee and magazines until $10 \mathrm{pm}$. When meeting the researchers, R2 justify the habit of selling their children until the evening. He was training his children to work early to help meet the needs of his family, even when the children did not want to work, R2 was not reluctant to beat and scold their children.

Respondent 3 or R3 is female aged 28 years. R3 has the educational background of junior high school. He worked as a store clerk. She has a husband and three children. Her husband works as a tire repairman. R3 worked from morning until evening, when R3 work, their children joined his father in the workshop. Their first child was 12 years old, he often helped his father get the tire in the garage. From the observation of R3 husband-mad very often blow up their children. Being asked, R3 said the reason she yelled at their children because the children are often fussy, especially the last children, and the brother also did not want to take care of. That's why husbands R3 instigating violence on their children. He also mentioned that if he had as a child too often scolded his parents so that he could now be submissive to parents. Thus, he also implemented it so that his son did not fight it. The violence not only by her husband's first child R3 alone but also shouts even hit his sister when her sister was not obeyed his sister.

The result showed that the violence on children of three respondents was physical abuse, including hitting and pinching, verbal abuse such as yelling and scolding the child. They also did social violence in the form of negligence. Besides, all respondents were asked to help meet their economic needs by means of selling newspapers, magazines, selling coffee, and wheel fillings services.

Based on interviews and observations with three survey respondents, it was obtained that the respondents did child abuse to educate children. They assume that by forcing the children, the children will be more submissive and feared by parents so that their children can follow the orders and the will of her parents. Besides, the way they educate children was adjusted to parenting applied by their parents. Their violence is considered as a natural thing. They also had a low educational background so that they did not understand how parenting was appropriate to be given to their children. Economic demand was also one of the factors that made them demand their children to work to help parents meet their daily needs. These results confirm the postulate of Rusmil stating that factors affecting child abuse in the family are economic factors, educational background of parents, parenting inherited, and internal factors of their own children as fussy and naughty[11].

Child abuse impacts significantly on children's emotion. Children become passive and withdrawn from the environment, defiant, aggressive, and sometimes criminal acts, and became persecutors as adults. Besides, children are also less able to honor his parents, they do not have their own personality. What they do is merely to fulfill the wishes of his parents. 
They are also not able to respect himself, and the most severe is the emergence of extraordinary hatred against himself because he felt only he is always wrong, causing the torture on him, and hatred against itself can cause self-harm acts.

\section{Conclusions and Recommendations}

\subsection{Conclusion}

Violence against children in the family is caused by several factors, including the ignorance of the parents against the impact of the violence per se, the family economic factors, the level of parental education, delinquency, and parenting inherited from their parents.

\subsection{Suggestion}

In children education, there is no such word called violence. Violence is the difference from the firm. Violence always involves emotion (do with emotional) while the firm is something that is done without any compromise. If the children education is filled with emotion, the dominant role of man will be the reptilian brain (reptile brain reflex serves to regulate movement and balance in the human body).

At the time of brain, the reptile is working, the rational thought that originates in the front brain (the hypothalamus) cannot work well, and this is the cause of parents being regret after doing violence to children since they are often angry or even vent emotions that are not controlled to children.

If the parents have problems and cannot think rationally, they should look for other things as cooling down or neutralize their anger so as not affect their children. Parents need to think before acting on the impact of their treatments. Importantly, parents should also study the psychological phase of children development and education so that they have a better understanding of the situation of children and do not need to use violence.

\section{References}

[1] S. Gerintya, "73,7 Persen Anak Indonesia Mengalami Kekerasan di Rumahnya Sendiri,” 2017. [Online]. Available: https://tirto.id/737-persen-anak-indonesia-mengalami-kekerasan-di- rumahnyasendiri-cAnG.

[2] P. R. Indonesia, "Undang-Undang Republik Indonesia Nomor 23 Tahun 2002 Tentang Perlindungan Anak," Jakarta, 2002.

[3] A. Huraerah, Kekerasan Terhadap Anak. Bandung: Nuansa Cendikia, 2018.

[4] R. Barker, The Social Work Dictionary, National Asspciation of social workers. 1978.

[5] R. Barker, The Social Work Dictionary. Maryland, Silver Spring: National Asspciation of social workers Press, 1978

[6] U. Sadullah, "Pedagogik." PT. Alfabeth, Bandung, p. 103, 2010.

[7] Tarsono, "Implikasi Teori Belajar Sosial (Social Learning Theory) Dari Albert Bandura Dalam

Bimbingan Dan Konseling," Psympathic, J. Ilm. Psikol., vol. III, no. 1, pp. 29-36, 2010.

[8] S. P. Shelov, Caring For Your Baby and Young Child. New York: Bantam Book, 1993.

[9] A. Dariyo, Psikologi Perkembangan Anak Tiga Tahun Pertama. Bandung: PT. Refika Aditama, 2007.

[10] N. Sa ida and A. P. Rahayu, "Penggunaan Wabosang Sebagai Media Pendidikan Seksual Pada Anak-Anak Bantaran Sungai Jembatan Merah Surabaya,” Aksiologiya J. Pengabdi. Kpd. Masy., vol. 2, no. 1, pp. 50-59, 2018. 
[11] K. Rusmil, "Penyalahgunaan dan kekerasan terhadap anak," in on day seminar "Handling of Victims of Violence on Women and Children" on 19 June at Hasan Sadikin Hospital, 2004, p. 60.

[12] R. Gelles, "Child Abuse," 2004. [Online]. Available: htpp; // Encarta.msn.com/encyclopedia. 